\title{
Impact measures for libraries and information services
}

\author{
Roswitha Poll \\ Münster, Germany \\ Philip Payne \\ Birkbeck College, University of London, London, UK
}

\begin{abstract}
Purpose: To demonstrate the importance of impact / outcome research in libraries

Design/methodology/approach: The paper gives an overview of purposes and methods used in impact research and illustrates this through project experiences.

Findings: Various projects worldwide are trying to prove that use of library services can positively influence skills and competences, attitudes and behaviour of users. The benefits that users experience by using library services can be assessed in terms of knowledge gained, higher information literacy, higher academic or professional success, social inclusion, and increase in individual well-being.
\end{abstract}

Research limitations/implications: The main problem of impact research is, that influences on an individual are manifold and that therefore it is difficult to trace changes and improvements back to the library. The paper shows methods that are tested and used at the present. More investigation is needed to identify methods that could be used to show a library's overall impact or to develop measures that would permit benchmarking between institutions.

Practical implications: The paper shows practical examples of impact assessment, covering "soft" methods like surveys, interviews, focus groups, observation and quantitative methods like tests, analysis of publications, or usage data.

Originality/value: The paper acquaints libraries with a topic that is not yet well known and, by showing practical examples, demonstrates how libraries can attempt to assess their impact.

Keywords: Libraries, Information services, Research

Paper type: Research paper

"The search for an ultimate measure of benefit may be illusory." (Revill, 1990)

\section{The need for evidence}

The value of libraries for the individual and for society has long been seen as selfevident. However, in times when users are becoming increasingly independent in their information seeking, when information seems to be free on the web (even where libraries have paid for access), and physical visits to libraries may decrease, the benefits gained from funding libraries are questioned not only by funding institutions but also by the public. Funding libraries is an expensive business: print and electronic collections, buildings and equipment, and especially staff costs, constitute a considerable factor in the budget of universities or communities. The questions are:

- Does investment in libraries represent value for money?

- $\quad$ Are there tangible, demonstrable effects arising from library use?

- Do such effects serve the goals of the funding institution?

- Could such effects be achieved without the existence of the particular library? 
In the competition for scarce resources, it becomes vital for libraries to show evidence of the impact and value of their services, preferably in quantified results. "Outcome-based evaluations can be thought of as an accountability measure..." (Hess and Klekotka, 2005, p. 272). Librarians themselves are of course convinced of library benefits. In the Alexandria Manifesto, adopted in 2005 in preparation for the World Summit on the Information Society, the International Federation of Library Associations and Institutions (IFLA) sees library benefits in the following fields (IFLA, 2005):

- democracy,

- intellectual freedom,

- information literacy,

- information equality,

- reduction of poverty,

- cultural diversity.

But how can we prove what we believe?

\section{Impact of libraries}

Libraries have always been able to calculate the inputs into services (funding, staff, collections, space, equipment) and have become increasingly sophisticated in measuring the outputs of those services (e.g. loans, visits, downloads, reference transactions). Measures have also been developed to assess the quality of library services and the cost-efficiency of the library's performance. But quantity of use and quality of performance do not yet prove that users benefited from their interaction with a library. Measuring impact or outcome means going a step further and trying to assess the effect of services on users (Figure 1).

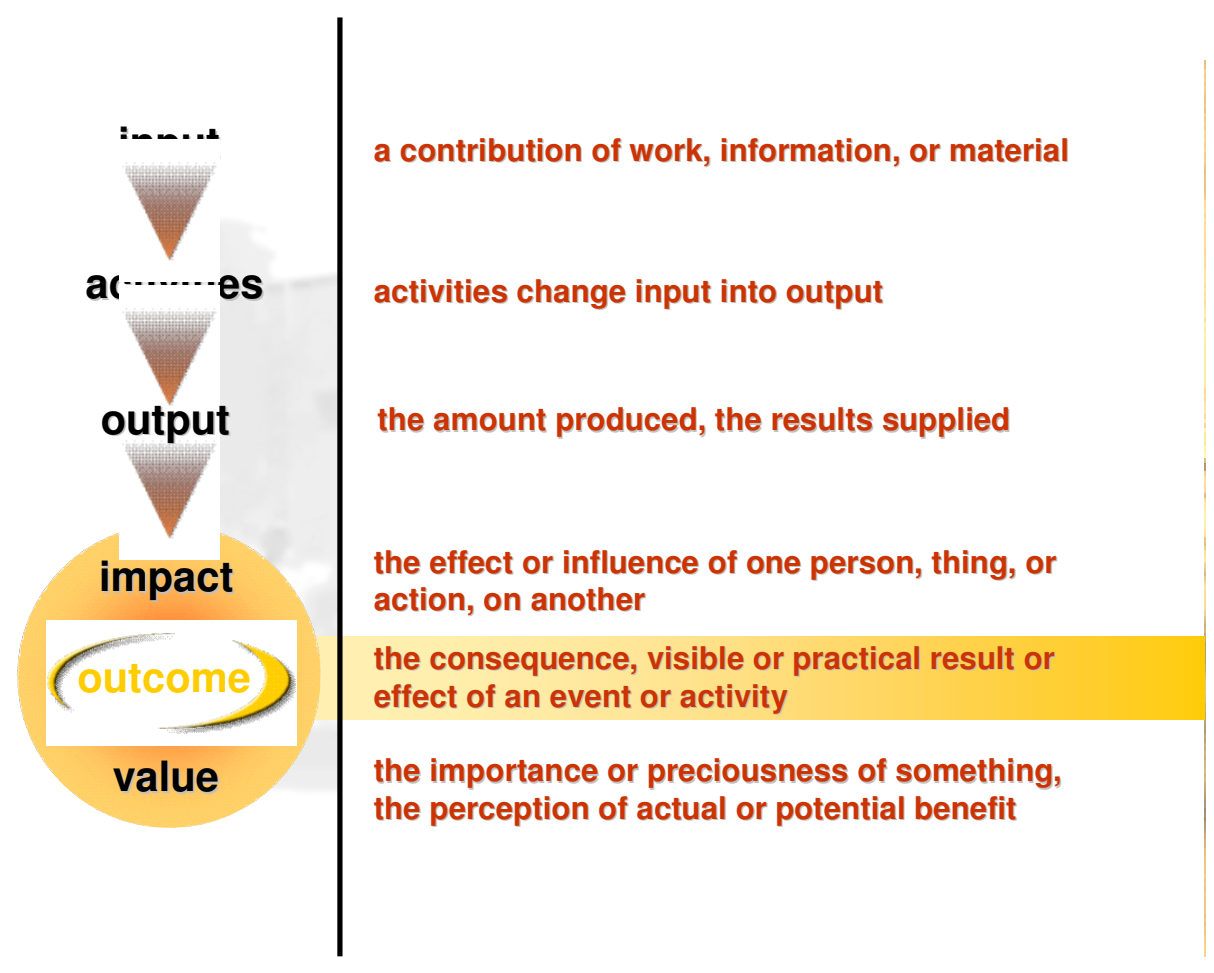

Figure 1: From input to impact / outcome 
"Impact" and "outcome" are often used synonymously in the professional literature. "Value" or "benefit" are generally broader terms. Definitions of library outcome generally highlight the effect on individual users or on users collectively. Impact links this with the library's aims and objectives and their relationship with its host institution's goals. Revill (1990) describes outcomes as follows:

Outcomes can be seen as the eventual result of using library services, the influence the use had, and its significance to the user. (p. 360)

This is echoed by the Association of College and Research Libraries in the USA:

Outcomes are the ways in which library users are changed as a result of their contact with the library's resources and programs. (ACRL, 1998)

The existence of a library and the use of its services can effect changes in skills, competences, attitudes and behaviour of its users, similar to changes effected by other cultural institutions like museums or archives.

Generally speaking, outcomes of cultural institutions include:

- knowledge,

- information literacy,

- $\quad$ higher academic or professional success,

- $\quad$ social inclusion (e.g. of elderly people or immigrants),

- individual well-being.

Such outcomes may appear in different ways. Hopefully, they will be positive, but there is also the possibility of negative outcomes: A bad experience during a library visit can result in a negative attitude to library use. Outcomes may be direct, immediate (finding useful information) or long-term (gaining information seeking competences). Actual benefits to the individual user differ from the potential benefits, the preciousness of a library's existence for issues like local culture or children's literacy. Finally, there may be intended and unintended outcomes. Intended outcomes are those that the library aims at according to its mission and goals. Unexpected outcomes - like people finding social contacts in the library can nevertheless further the positive attitude to library use.

Outcomes, as research shows,

- $\quad$ are not always predictable,

- are generally rather an addition to previous experience than a radical change in attitudes,

- $\quad$ will be higher if a gain in skills and competences or a change in behaviour seems promising to the user,

- $\quad$ often become visible only in long-term development.

\section{Impact planning}

Most libraries are part of an institution - a community, a school, a commercial firm, or a university - and the library's mission and goals must be adjusted to those of its parent institution. The impact of library services should therefore support the institutional goals and the strategic aims of the institution.

A good example is the impact of libraries compared to the goals of universities. What universities want to achieve can be summarized thus:

- recruitment and retention of students and excellent academic staff;

- $\quad$ effective teaching, resulting in 
- high graduation rates,

- high grades in examinations,

- high employment rates after examinations;

- $\quad$ effective research, resulting in

- high valuation and use of research results and publications,

- high amount of special grants,

- status, awards, honours.

In summary, universities aim at achieving independence of thinking and judgement, competent use of information, thorough professional knowledge for their students, and research results of high relevance. Most of these goals can be supported by library services, and libraries should try to prove the connection between use of their services and the institution's success.

\section{Assessing impact - the problems}

Trying to show an impact of libraries on individuals and society is obviously a much more difficult venture than counting outputs. The following problems appeared in most studies:

- A service can have different value and outcome for different user groups. A training session in special databases will have less effect on freshmen than on postgraduates who need these resources directly for their work.

- Data that could be relevant for demonstrating impact are not available because of data protection rules (e.g. individual data about grades in exams).

- The data or correlations found in projects until now are in most cases not comparable, as differing methods were used. Standardization of methods will be necessary to allow for benchmarking of results.

- Long-term effects can often not be assessed if the users are no more available for tests or surveys.

- $\quad$ All methods that have been tested until now are time-consuming.

But the most challenging problem is that it is nearly impossible to separate library impact from other influences and to prove that changes in competences or behaviour are indeed an effect of using library services. Influences on individuals are manifold. Users may have gained information and competences from friends or teachers, from using media outside the library or searching the Internet. As it is often not possible to find positive proof of a direct influence of the library, surrogate measures must be used that at least indicate some influence. These problems are most troublesome when assessing the overall impact of a library and its services. They become less apparent in evaluating the outcome of one single activity like implementing a new service or conducting a user training programme, as the behaviour and skills before and after the implementation or the training can be more readily measured. Another difficulty is that it may take time before the impact of a library's interventions becomes clear. As Everest and Payne (2001) state:

Assessing impact is not easy and it is not an exact science. We are dealing with a changing environment where people, services, and needs are constantly evolving. Any research will inevitably provide a snapshot of what is happening at a particular point in time. (p. 21) 


\section{Methods for assessing impact}

The ways that have been used for showing impact can be differentiated into quantitative and qualitative methods. Quantitative methods try to measure changes in competences or behaviour or to find correlations between library use and a person's academic or professional success. The following methods have been used:

- tests that assess user skills before and after a training or the use of a library service,

- performance monitoring/data mining,

- unobtrusive observation,

- analysis of citations in course work or research publications,

- comparison of success data with use data.

Qualitative ("soft") measures, developed in social science, try to assess outcomes by evaluating users' experiences and opinions. Methods used are:

- $\quad$ surveys (print, telephone, or online),

- interviews,

- focus groups, discussion groups,

- users' self-assessment of skills and competences gained.

Exit surveys (surveys conducted on leaving a service) can be especially useful as they can immediately catch users' impressions about having benefited. Selfassessment has proved less reliable, as users tend to rate their own competences somewhat higher than they really are. Qualitative methods supply a rich fund of "stories" about personal experiences and judgements. These stories must be organized in order to recognize patterns and crucial points and - if possible - to show statistics of outcomes as to user groups. The results of qualitative methods will of course have a subjective bias; they show the "perceived outcome". They should therefore be compared with results of quantitative methods or with statistics of library use in order to validate the results. But the "anecdotal evidence" will be invaluable in reporting to the public and the institution, as it serves to make statistics understandable and believable.

There is a debate in outcome research as to whether user satisfaction could serve as an outcome measure. As user satisfaction surveys are now well established in libraries, it would be easy to use the results for assessing the impact of libraries. But is satisfaction with the library or with a library service indeed an outcome in the sense of benefits? Opinions are divided:

Satisfaction on the part of a user is an outcome. So is dissatisfaction. The Task Force considers simple satisfaction a facile outcome, however, too often unrelated to more substantial outcomes that hew more closely to the missions of libraries and the institutions they serve. (ACRL, 1998)

Customer satisfaction [...] is neither outcome nor output. Rather, it is a qualitative assessment of library outputs [...]. (Cram, 2000, p. 23)

User satisfaction surveys ask for a user's direct or long-term experience with library services or for experience compared to expectation. High satisfaction could mean that the library has been effective in conveying the view: It is well worth to use a library. But this does not mean that there is already a change in skills, competences, and behaviour. User satisfaction could rather be seen as giving a 
good basis for such changes in furthering receptivity and thus rendering outcomes possible.

\section{The topics of impact assessment}

Projects of impact assessment can be grouped as to the following topics:

- Correlation of library use and academic or professional success

- The library's impact on information literacy

- The importance of the local library for research

- The social impact of libraries

- The financial value of libraries

Correlation of library use and academic or professional success. Statistics of the frequency and intensity of library use are compared to data of individual success. Research in this area has concentrated on academic success of students. Library use is expressed in data about

- the frequency of use (e.g. of loans or visits),

- the range of services used (e.g. reference service, user training, interlibrary loan),

- the range of collections used (e.g. not only the undergraduate collection but E-journals, special material),

- $\quad$ attendances at training sessions.

Academic success is expressed in terms of

- $\quad$ short studying times,

- high grades in examinations,

- student retention,

- high employment rate after examinations,

- the quality of publications (high impact factor, publishing in peer-review journals).

Projects have not always found a statistically valid correlation between library use and academic success. The most interesting results are probably those of the Department of Information and Library Studies of the University of Cape Town (de Jager, 1997 and 2002). The projects tried to find out whether students had only used the basic literature in "Short Loan Material" or had gone on to the more special literature in the general collection. When comparing the data not of individuals but of groups, the results showed that students with a high grade in examinations had indeed used the specialized literature to a higher degree. But such data related to individuals will not be available everywhere because of data protection rights. And the question remains whether the quick and successful examination was (also) an effect of library use.

The library's impact on information literacy. Outcome research in libraries has concentrated very much on this issue, due to the importance of showing "learning outcomes" in education. Libraries are more and more integrated in information literacy teaching in universities, especially in bachelor/master studies. The new role of the "teaching library" calls for assessment of teaching results. Methods for measuring outcomes of user training have been already well tested and even standardized. They include 
- surveys after instruction,

- pretest / post test,

- self-assessment of users,

- behavioural observation,

- transaction logs,

- longitudinal studies,

- $\quad$ assessing changes in students' bibliographies.

Tests, especially combinations of pretest and posttest, are the preferred method (Brown and Krumholz, 2002; Dunn, 2002; Fister, 2003; Mark, 2004). In the last years, citation analysis has also been used for assessing changes in users' information literacy competences (Beile et al., 2004; Middleton, 2005; Tuñon and Brydges, 2005). Whatever method was used, it seemed in most cases possible to show direct impact of library training and services on information literacy.

The importance of the local library for research. Citation analysis is also used for showing a library's value for research in its institution (Ahtola, 2002; Smith, 2003). The citations in bibliographies of dissertations, research papers or students' papers are compared with the library's print and electronic collection. The question is: What percentage of the material cited was (or could have been) retrieved via the local library?

In order to check whether the materials were indeed taken from the library collection, a survey to, or interview with, the authors might be added. Questions could be:

- Where did you find the material you cited in your publication?

- $\quad$ Could you have achieved a similar result without your local library?

The University and Regional Library Münster, Germany, examined 7016 citations in 20 doctoral dissertations and found that $70.8 \%$ would have been available via the library. A survey to the authors corroborated the data: 15 of the 20 authors said they had frequently retrieved their information from the local library system (Kayß and Poll, 2006). This method is certainly one of the "surrogate measures" for assessing library outcomes.

The social impact of libraries. In this complex of questions, libraries try to show the value of libraries for the individual (direct benefit) or society (indirect benefit). Methods used are interviews, surveys or focus groups with actual and potential users. In most cases questions as to sociodemographic data (age, gender, ethnic group, income, employment status, educational grade) and as to library use (frequency, services used) are added in order to have a background for recognizing patterns in the answers.

Users and non-users are asked for

- direct benefit from a library use,

- potential benefit for the interviewee by this library,

- indirect (potential) benefit of a library's existence (e.g. free access to information, cultural life in the community, children's literacy, social inclusion),

- $\quad$ potential value of the library for future users.

Projects for assessing social impact have been frequent in public libraries (Bohme and Spiller, 1999; Debono, 2002; Linley and Usherwood, 1998). 
Results of social impact projects should be compared with statistics of library use and library user groups that can show developments in the choice of services used and the percentages of active users out of certain groups (e.g. fringe groups).

The financial value of libraries. Measuring the value of libraries in terms of money is certainly the issue of impact assessment that would be most interesting to the funding institutions.

As most library services have no equivalent on the common market and therefore no "market prices" can be determined, two other ways have been tried for assessing an economic value:

- $\quad$ assessing time costs ("replacement value of a client's time"),

- $\quad$ using the contingent valuation method.

The time costs method is based on the assumption: Users invest time and effort in order to use library services. The value that they - or their institution place on that use must be at least as high as their "sacrifice" of time. Time costs are calculated by multiplying users' time spent with library services with the average salary costs of the population served by that library. The method has been used in special libraries, but does not fit e.g. student populations.

The contingent valuation method has been developed in order to assess the financial value of non-profit organizations and services, especially projects in health care, environmental protection, education or culture. Persons directly or potentially interested in such services are asked to rate the value in financial terms, expressed by their

- willingness-to-pay: What would you pay for maintaining this library/this special library service?

- $\quad$ willingness-to-accept: Which sum would you accept as an equivalent if this library/this special library service were given up?

In the surveys or interviews, people are given options between sums they would pay (e.g. in higher taxes) or accept (e.g. in lower taxes). The difficulty in such surveys is that people are asked to financially rate services or institutions that they never thought of in terms of money. In the answers, the willingness-to-pay is often somewhat lower than the willingness-to-accept, as people are afraid to name a sum they would pay. Examples for the use of the contingent valuation method are already frequent in the sector of public libraries (Morris et al., 2001; Holt et al., 1999; Aabø, 2005). The best-known example is that of the British Library (Pung et al., 2004) that came out with the result: For every $£ 1$ of public funding the British Library receives each year, $£ 4.4$ is generated for the economy. Such data are indeed invaluable in reporting.

\section{Using the results}

Results of impact assessment can be used for several purposes:

- accountability, justification of resources used and services offered;

- decision making and resource management;

- improvement of services in order to achieve higher outcomes;

- benchmarking with libraries of similar structure and mission.

But the most urgent issue is to promote the library's role, to show what one library, what all libraries can do for their users and society. Libraries are too often 
forgotten in legislation, in community or institutional planning, or when setting priorities in funding. They should actively promote the benefits derived from their services and substantiate such statements with the evidence of data and lively stories. "Libraries on the agenda" will be the presidential theme of the next IFLA president, Claudia Lux; impact assessment can help to put libraries in the limelight.

Assessing the value of libraries is no easy task. Intangible issues like the impact on knowledge, competences and behaviour of persons must be made visible and understandable. "Searching for the most elusive indicators" (de Jager, 2001), "Six impossible things before breakfast" (Cram, 2000): papers on outcome measures show the difficulty.

\section{The LIRG / SCONUL Impact Initiative: practical examples of assessing impact}

\section{Background to the Initiative}

The LIRG / SCONUL Impact Initiative has been concerned with assessing the impact of higher education libraries in the UK on learning, teaching, and research. In the context of the Initiative, 'impact' has been seen in terms of whether libraries have made a difference as a result of a variety of different interventions. The Initiative has then sought to develop methodologies which can be used by institutions to measure the difference that they have made.

The Initiative has not sought to assess a library's overall impact. It has not been looking, for example, at a library's impact on student achievement. Instead, a project-based approach has been adopted. Individual institutions participating in the Initiative have been investigating their impact in relation to particular services or-innovations. The areas that participating institutions have investigated usually relate to the library's strategic goals and to their change agendas. Not surprisingly, the choice of topics to investigate has often been guided by the strategic aims of the host institution. The libraries have sought to show their contribution to the work of their institutions. The Initiative has been concerned with developing methodologies that can be used to assess a library's impact.

The Initiative overall has effectively been an umbrella for a number of institution-based projects which have been conducted at the same time using a common approach. By taking a co-ordinated approach, we have sought to encourage the sharing of experience between those institutions participating in the Initiative. Participants in the Initiative have been supported by facilitators. The facilitators have been consultants with expertise in assessing library impact (Markless and Streatfield, 2005). They have assisted in setting up the institutional impact projects using an 'impact process model' that they had developed in previous work, and reviewing progress. Most of the support has been delivered through workshops that have been run at the start, midway, and end of the programme.

When the Initiative began, it had been hoped to develop sector-wide impact measures but this was found to be over-optimistic. It soon became clear that, in view of the different institutional contexts and priorities, this could not be achieved within the timescales of the Initiative. When more experience has been built up of assessing impact, benchmarking impact between comparable institutions might be possible. 


\section{Participants in the Initiative}

Who has been involved with the Initiative? The Library and Information Research Group (LIRG) is a special interest group of the UK's Chartered Institute of Library and Information Professionals (CILIP). LIRG aims to promote the value of information research and to link research with practice. The Society of College, National and University Libraries (SCONUL) has provided support through its Working Group on Performance Improvement. As indicated earlier, the Initiative has been facilitated by David Streatfield and Sharon Markless of Information Management Associates (IMA). IMA have a strong track record in assessing library impact, primarily in relation to health libraries, further education college libraries, and school libraries. They also have considerable research experience and expertise in research methodologies.

The other participants in the Initiative have been the institutions themselves. There have been two phases of the Initiative. Phase 1 ran from July 2003 until July 2004 and involved 10 institutions (Table 1). Phase 2 ran from July 2004 until December 2005 and involved 12 institutions (Table 2). All participating institutions responded to a call for volunteers. We were seeking a good range of institutions institutions in different parts of the UK, of different sizes, and of different types.

\begin{tabular}{|c|c|}
\hline Birkbeck College & Impact of an online induction tutorial \\
\hline University College Chester & Impact of investment in electronic resources \\
\hline Glasgow Caledonian University & $\begin{array}{l}\text { Information literacy strategy: awareness of the strategy and its } \\
\text { impact }\end{array}$ \\
\hline University of Gloucestershire & Impact of an online information skills tutorial \\
\hline University of Leeds & Impact of information literacy initiatives \\
\hline Leeds Metropolitan University & $\begin{array}{l}\text { Information literacy strategy: awareness of the strategy and its } \\
\text { impact }\end{array}$ \\
\hline Northumbria University & $\begin{array}{l}\text { Impact on improving students' confidence and competence in } \\
\text { information and IT skills }\end{array}$ \\
\hline Open University & $\begin{array}{l}\text { Information literacy programme: impact on information literacy } \\
\text { amongst students }\end{array}$ \\
\hline University of Teesside & Impact of library support to partner institutions \\
\hline University of Warwick & Impact of the library on the research process \\
\hline
\end{tabular}

Table 1: Institutions in phase 1 of the LIRG / SCONUL Impact Initiative

The two sponsoring organisations, LIRG and SCONUL, contributed a small amount of pump-priming funding at the outset. Otherwise, the costs of participation have been covered by the libraries that have volunteered to be involved in the Initiative. Pooling resources and benefiting through combined efforts was therefore a major feature of the Initiative. 


\begin{tabular}{|c|c|}
\hline University of Birmingham & Institutional Repository and Scholarly Communications Advocacy \\
\hline Bournemouth University & Equality of access to e-resources \\
\hline Brunel University & Information skills for research postgraduates \\
\hline University of Edinburgh & Subject-specific electronic resources and the research process \\
\hline University of Glasgow & Subject-specific electronic resources and the research process \\
\hline King's College & Integrated enquiry desks \\
\hline Newman College & Support for widening participation \\
\hline University College Northampton & Support for widening participation \\
\hline University of Southampton & Library support for non-traditional students of modern languages \\
\hline Staffordshire University & Single point of access for IT and library enquiries \\
\hline University of Stirling & Student use of subject resources web pages \\
\hline $\begin{array}{l}\text { University of the West of } \\
\text { England }\end{array}$ & $\begin{array}{l}\text { Increasing amounts spent on electronic information services (EIS) } \\
\text { each year }\end{array}$ \\
\hline
\end{tabular}

Table 2: Institutions in phase 2 of the LIRG / SCONUL Impact Initiative

\section{Process adopted by the Initiative}

Participating institutions were required to identify an area where they wished to assess their impact. Although we were interested in covering a wide range of topics, a convergence emerged early on which led to eight of the ten institutional projects being concerned with information literacy. Other topics covered in Phase 1 were e-resources, impact of library support on the research process, and the impact of library services to partner institutions. As the focus of Phase 1 had been so strongly on information literacy, we were determined to cover a wider range of topics in Phase 2. Five of the twelve institutions looked at e-resources, two looked at support for institutional widening participation initiatives, and two looked at the impact of converged library and IT help desks. Other projects covered library support for non-traditional students of modern languages, information skills for research postgraduates, and advocacy for institutional repository and scholarly communication. A special issue of LIRG's Library and Information Research provides overviews of Phase 1 (Payne and Conyers, 2005; Markless and Streatfield, 2005; Blagden, 2005) plus reports from each of the ten participating libraries.

All of the projects followed a common approach which involved:

1. Choosing an area where the library was seeking to assess impact.

2. Articulating objectives that set out what the library was seeking to achieve in the chosen area.

3. Developing success criteria against which a judgement can be made as to whether the objectives have been met.

4. Creating impact measures for the chosen area of investigation. 
5. Identifying evidence that needed to be collected in respect of these impact measures.

6. Selecting appropriate research methods to collect that evidence.

The following example illustrates the stages that were followed. Learning Support Services at Leeds Metropolitan University had developed an information literacy framework and wanted to assess the impact of the framework on learning and teaching in the University. For each objective of the information literacy framework, they identified success criteria by which they could judge whether or not the library had been successful in what it had set out to do. They then chose the research methods that they would use in order to gather the evidence of whether or not they had been successful (Everest et al., 2005). These objectives in respect of an information literacy framework were shared with Glasgow Caledonian University (Crawford, 2006).

\section{Information Literacy Project (Leeds Metropolitan University)}

Objective 1. To raise awareness of the importance of information literacy amongst students and academic staff

- Success Criteria: Every member of academic staff aware of the Information Literacy Framework

- $\quad$ Evidence \& collection method: Learning advisers to carry out personal or telephone interviews to assess level of awareness

Objective 2. To equip students with the skills to become independent seekers and discerning users of information in their studies

- Success Criteria: More diverse range of information sources cited in bibliographies

- Evidence \& collection method: A team of Learning Advisers to review student bibliographies before and afterwards in partnership with selected academic staff

Objective 3. To integrate information literacy into the student curriculum

- Success Criteria: Evidence that information literacy is increasingly integrated within the curriculum

- $\quad$ Evidence \& collection method: To use an information literacy teaching audit to assess current level of integration

\section{Methods used to collect evidence}

What sorts of methods were used by participants in the Initiative? Statistics on usage were important for many of the projects. Often these already existed and did not require additional data collection. There was particular interest in using statistics on the use of e-resources. Questionnaires, interviews, and testing students' skills levels after library interventions were frequently used. However, the projects demonstrated considerable diversity in the data collection methods used. The methods chosen tended to have an emphasis on qualitative 'soft' methods. The emphasis on softer methods was not surprising as the Initiative was based on action research. Markless and Streatfield (2006) highlight the appropriateness of this approach to the Initiative: 
Action research as a form of social research is not a detached specialised, technical activity but one closely linked to reflective practice, designed to be undertaken by practitioners and empower them. (p. 4)

\section{Outcomes of the Initiative}

What did the participants achieve through participation? Institutions reported very different experiences of participation in the Initiative. Some struggled and others found it deeply rewarding. However, many of the projects reported that the Initiative led to:

- deeper understanding of how the library supports academic processes,

- improved dialogue with academics and stakeholders,

- misconceptions (amongst library staff and amongst stakeholders) being challenged,

- the development of library staff - particularly in respect of their understanding of the contribution of the Library to learning, teaching, and research - but also in developing new skills,

- $\quad$ a raised profile for the library within the organisation.

The outcomes for individual institutions have been interesting. Everest et al. (2005), for example, describe how the information literacy framework at Leeds Metropolitan University was produced as a booklet and circulated to all academic staff. Learning Advisers subsequently conducted telephone interviews and found that over $50 \%$ of academics had received the booklet and read it. However, around $20 \%$ of those who had received the booklet had not read it. The project team also analysed bibliographies from student dissertations, developing criteria for what constitutes a 'good' bibliography with academic staff. They report that initial results show that information skills teaching had lead to an improvement in the quality of student bibliographies. Glasgow Caledonian University shared the same project objectives around information literacy as Leeds Metropolitan University. Surveys of current students and alumni were carried out. The study clearly demonstrates the difficulties of seeking to measure impact: identifying the Library's contribution separately, linkages with other variables, and discipline differences in the student population. The study concluded that there was a more sharply focused appreciation of the importance of the information literacy skills, skills taught at University, amongst alumni than current students (Crawford, 2006). This highlights the importance of seeking to measure longer-term impacts.

In another example, the University College Chester demonstrated that, by having librarians working closely with academic staff in making links to high quality e-resources from Virtual Learning Environment (VLE) modules, there was increased use of them. They were able to use this evidence to argue for additional staffing (Payne et al., 2004).

What did the Initiative achieve overall? First, and perhaps most important, it has highlighted the importance of seeking to measure impact. Secondly, the Initiative has explored methods for measuring impact. Thirdly, the Initiative has built up a network of experience of measuring impact. It has also produced examples and tools that can be more widely shared. Participants have felt that the materials and experience could be built upon to support the creation of a 'community of practice'. Finally, the Initiative has also promoted practitioner-based 
research. Twenty-two institutions have been involved in projects that they may not otherwise have undertaken.

The Initiative has confirmed that it is not easy to assess impact. This is primarily because we are usually dealing with assessing the impact on people changes in their behaviour, knowledge, awareness, competencies, and attitudes. Not only are these things difficult to measure, but it is often a challenge to disentangle our contribution to the change from the contribution of others.

The Initiative was not without difficulties. Participants at the end of Phase 2 noted several problem areas. First, it was often difficult to find the time to undertake the work. Most participants reported that it took more staff time than they had anticipated. Some found that pressing operational priorities interfered with their ability to conduct their impact study. Secondly, participants felt that there was a need to encourage greater sharing of experience between participating institutions. There were a couple of examples of collaborative projects across the two phases of the Initiative but this might have been encouraged more. Thirdly, in view of the more extensive of 'softer' methods, participants felt that they needed more assistance in the use of qualitative research methods and in the analysis of qualitative research data. Fourthly, participants felt that there was a need to take greater account of prior experience of conducting research and adjust the support accordingly. Fifthly, participants would have liked more ongoing support between events. This included a more pro-active approach to nudging and encouraging the project teams. Finally, participants felt that there was a need for greater clarity at the outset of what was expected in terms of participation.

However, participating institutions did find that attempting to assess their impact is worthwhile. Managers discovered that undertaking this work has helped managers and practitioners by providing evidence of the effects of new services or innovations. This supports the management of change. But, it goes further. Seeking to assess impact moves us from traditional views of service quality, based on such things as use statistics and satisfaction surveys, to looking at the deeper issues associated with our contribution to learning, teaching, and research.

\section{References}

Aabø, S. (2005), "The value of public libraries in Norway", Bibliotekforum, Vol. 6, pp. 38-40.

Ahtola, A.A. (2002), "How to evaluate and measure the impact of the library's collection on the learning outcome?", paper given at the 68th IFLA Glasgow 2002 , available at: www.ifla.org/VII/s2/conf/ahtola.pdf (accessed 11 February 2006).

Association of College and Research Libraries (ACRL) (1998), "Task force on academic library outcomes assessment report", available at: www.ala.org/ala/acrl/acrlpubs/whitepapers/taskforceacademic.htm (accessed 11 February 2006).

Beile, P.M., Boote, D.N. and Killingsworth, E.K. (2004), "A microscope or a mirror? A question of study validity regarding the use of dissertation citation analysis for evaluating research collections", The Journal of Academic Librarianship, Vol.30, No.5, pp. 347-353. 
Blagden, P. (2005), "The LIRG / SCONUL Measuring Impact Initiative overview of phase 1 impact projects", Library and Information Research, Vol. 29, No. 91, pp. 14-15, available at: www.cilip.org.uk/specialinterestgroups/bysubject/research/publications/jour nal/archive/lir91/91_blagden.htm (accessed 27 February 2006).

Bohme, S. and Spiller, D. (Eds.) (1999), Perspectives of Public Library Use 2. A Compendium of Survey Information, Library \& Information Statistics Unit (LISU), Loughborough.

Brown, C. and Krumholz, L.R. (2002), "Integrating information literacy into the science curriculum", College and Research Libraries, Vol.63, pp. 111-123.

Cram, J. (2000), "Six impossible things before breakfast: a multidimensional approach to measuring the value of libraries", in Proceedings of the 3rd Northumbria International Conference on Performance Measurement in Libraries and Information Services, University of Northumbria, Newcastle upon Tyne, pp. 19-29, available at: www.alia.org.au/ jcram/six_things.html (accessed 11 February 2006).

Crawford, J. (2006), "The use of electronic services and information literacy: a Glasgow Caledonian University study", Journal of Librarianship and Information Science, Vol. 38, No. 1, pp. 33-44.

Debono, B. (2002), "Assessing the social impact of public libraries: what the literature is saying", Australasian Public Libraries and Information Services, Vol. 15, No. 2, pp. 80-95.

De Jager, K. (1997), "Library use and academic achievement", South African Journal of Library and Information Science, Vol. 65, pp. 26-30.

De Jager, K. (2001), "Impacts \& outcomes: searching for the most elusive indicators of academic library performance", in Meaningful measures for emerging realities. Proceedings of the 4th Northumbria International Conference on Performance Measurement in Libraries and Information Services, Association of Research Libraries, Washington D.C., pp. 291-297, available at: www.arl.org/stats/north/powerpoints/dejager-pt4nor2.ppt (accessed 11 February 2006).

De Jager, K. (2002), "Successful students: does the library make a difference?", Performance Measurement and Metrics, Vol. 3, pp. 140-144, available at: http://zerlina.emeraldinsight.com/pdfs/awards2003/pmm2.pdf (accessed 11 February 2006).

Dunn, K. (2002), "Assessing information literacy skills in the California State University: a progress report", The Journal of Academic Librarianship, Vol. 28, pp. 26-35.

Everest, K. and Payne, P. (2001), "The impact of libraries on learning, teaching, and research: report of the LIRG seminar held in Leeds $30^{\text {th }}$. October 2001", Library and Information Research, Vol. 25, No. 81, pp. 18-22, available at: http://eprints.rclis.org/archive/00003337/01/article81c.pdf (accessed 20 April 2006).

Everest, K., Scopes, M. and Taylor, J. (2005), "Leeds Metropolitan University: the impact of the information literacy framework, Library and Information Research, Vol. 29, No. 91, pp. 26-27, available at: www.cilip.org.uk/specialinterestgroups/bysubject/research/publications/jour 
nal/archive/lir91/91_everest_scopes_taylor.htm (accessed 27 February 2006).

Fister, B. (2003), "What do they know? Assessing the library's contribution to student learning", Library Issues, Vol. 23, No. 3.

Hess, F.M. and Klekotka, A.L. (2005), "Impact / outcome evaluation", in Encyclopedia of Social Measurement, Vol. 2, pp. 271-276.

Holt, G. E., Elliott, D. and Moore, A. (1999), "Placing a value on public library services", Public Libraries, Vol. 38, pp. 89-108.

International Federation of Library Associations and Institutions (IFLA) (2005), Alexandria Manifesto on Libraries. The Information Society in Action, available at: www.ifla.org/III/wsis/AlexandriaManifesto.html (accessed 11 February 2006).

Kayß, M. and Poll, R. (2006), „Unterstützen Bibliotheksbestände die Forschung? Zitatanalyse in Dissertationen", B.I.T. online, No. 2/2006 (forthcoming).

Linley, R. and Usherwood, B. (1998), New Measures for the New Library: a Social Audit of Public Libraries, British Library Board, London, (British Library Research and Innovation Centre Report 89), available at: www.ifla.org/IV/ifla64/054-94e.htm (accessed 11 February 2006).

Mark, A.E. (2004), "Assessing student learning. Available resources”, College and Research Libraries News, Vol. 65, pp. 254-256, available at: www.ala.org/ala/acrl/acrlpubs/crlnews/backissues2004/may04/studentlearni ng.htm (accessed 11 February 2006).

Markless, S. and Streatfield, D. (2005), "Facilitating the impact implementation programme", Library and Information Research, Vol. 29, No. 91, pp.8-13, available

at: www.cilip.org.uk/specialinterestgroups/bysubject/research/publications/jour nal/archive/lir91/91_markless_streatfield.htm (accessed 27 February 2006).

Markless, S. and Streatfield, D. (2006), "Gathering and applying evidence of the impact of UK university libraries on student learning and research: a facilitated action research approach", International Journal of Information Management, Vol. 26, pp. 3-15.

Middleton, A. (2005), "An attempt to quantify the quality of student bibliographies", Performance Measurement and Metrics, Vol. 6, No. 1, pp. 7-18.

Morris, A., Hawkins, M. and Sumsion, J. (2001), The Economic Value of Public Libraries, Resource: The Council for Museums, Archives and Libraries, London, (= Library and Information Commission Research Reports, 89).

Payne, P. and Conyers, A. (2005), "Measuring the impact of higher education libraries", Library and Information Research, Vol. 29, No. 91, pp. 3-7, available

www.cilip.org.uk/specialinterestgroups/bysubject/research/publications/jour nal/archive/lir91/91_payne_conyers.htm (accessed 27 February 2006).

Payne, P., Crawford, C. and Fiander ,W. (2004), "Counting on making a difference: assessing our impact", VINE: The Journal of Information and Knowledge Management Systems, Vol. 34, No. 4, pp. 176-183.

Pung, C., Clarke, A. and Patton, L. (2004), "Measuring the economic impact of the British Library", New Review of Academic Librarianship, Vol. 10, No. 1, pp. 79-102. 
Revill, D. (1990), "Performance measures for academic libraries", in Kent, E. (Ed.), Encyclopedia of Library and Information Science, Dekker, New York, Basel, pp. 294-333.

Smith, E.T. (2003), "Assessing collection usefulness: an investigation of library ownership of the resources graduate students use", College \& Research Libraries, Vol. 64, No. 5, pp. 344-355.

Tuñon, J. and Brydges, B. (2005), "Improving the quality of university libraries through citation mining and analysis using two new dissertation bibliometric assessment tools", paper given at 71st IFLA Oslo 2005, available at: www.ifla.org/IV/ifla71/papers/078e-Tunon_Brydges.pdf (accessed 11 February 2006). 